\title{
Antimicrobial activity of crude extracts and fractions of Vernonia polyanthes Less (assa-peixe) flowers
}

WALTRICH, K.K.'; HOSCHEID, J.2*; PROCHNAU I.S.1.

${ }_{1}$ Pontifícia Universidade Católica do Paraná, Escola de Saúde e Biociências, 85902-532 Toledo - PR, Brasil; 2Universidade Estadual de Maringá, Departamento de Farmácia, 87020-900 Maringá - PR, Brasil. *Autor para correspondência: jaqueline.hoscheid@gmail.com.

\begin{abstract}
Antimicrobial activity of crude extracts and fractions of Vernonia polyanthes Less (assa-peixe) flowers. Vernonia polyanthes, known as "assa-peixe", is a plant native to Brazil, and the decoction or infusion of its flowers, roots and leaves are used in folk medicine, being considered sources of diuretic, balsamic, anti-rheumatic substances, and are used in cases of bronchitis and persistent cough. The aim of the study was to evaluate the antimicrobial activity of the extract/fractions obtained by methanol maceration and infusion of $V$. polyanthes flower, also including qualitative identification of flower compounds, through phytochemical evaluation, using colorimetric tests. Identification tests for the presence of anthraquinones, tannins, flavonoids, saponins and alkaloids were performed. Microbiological evaluation was made through agar diffusion assay, using Escherichia coli, Staphylococcus aureus and Pseudomonas aeruginosa as test organisms. From the performed colorimetric tests it was possible to verify the presence of tannins and flavonoids in both extracts. Alkaloids were also observed in the macerated extract. The ethyl acetate fraction from the agar diffusion assay, from both extracts, presented microbial activity over Staphylococcus aureus. It was possible to qualitatively identify the floral compounds, and to show the differences between extraction methods, being methanol considered the best solvent to the extraction.
\end{abstract}

Keywords: Assa-peixe; Cambará; Medicinal plants; Phytochemical profile.

\begin{abstract}
RESUMO: Atividade antimicrobiana de extrato bruto e de frações de flores de Vernonia polyanthes Less (assa-peixe). Vernonia polyanthes, conhecida como assa-peixe, é planta nativa do Brasil e suas flores, raízes e folhas, em decocção ou infusão, são empregadas na medicina caseira como diuréticas, balsâmicas, e anti-reumáticas, usadas nos casos de bronquite e tosse persistente. O objetivo do trabalho foi avaliar a atividade antimicrobiana do extrato/ frações obtidos por maceração em metanol e infusão de flores de $V$. polyanthes, incluindo também a identificação qualitativa dos compostos presentes nas flores, através da avaliação fitoquímica, empregando testes colorimétricos. Foram realizados testes para identificação de antraquinonas, taninos, flavonóides, saponinas e alcalóides. A avaliação microbiológica foi realizada por meio de ensaio de difusão em ágar, empregando Escherichia coli, Staphylococcus aureus e Pseudomonas aeruginosa. A partir dos testes colorimétricos foi possível verificar a presença de taninos e flavonóides em ambos os extratos. Ainda, no extrato macerado, foi observada a presença de alcalóides. No ensaio de difusão em ágar, a fração acetato de etila de ambos os extratos, apresentou atividade antimicrobiana sobre Staphylococcus aureus. Foi possível identificar qualitativamente os compostos da flor, demonstrando diferença entre as técnicas de extração, sendo que o metanol resultou em melhor poder extrativo.
\end{abstract}

Palavras-chave: Assa-peixe; Cambará; Plantas medicinais; Perfil fitoquímico.

\section{INTRODUCTION}

Family Asteraceae comprises about 1100 genera and 25000 species, and Vernonia is considered the family's most representative genus, including about 1000 species with high pharmacological potential (Zomlefer, 1994; Lorenzi \& Matos, 2008). The genus Vernonia, native to Brazil, 
is found in some regions from the states of Bahia, Minas Gerais and Santa Catarina, and is typically presented in the form of small shrubs to small trees. They present a high variability of leaves, which can be complete ors plit, and alternate or opposed to each other. Flowers are usually zygomorphic or bilabiate, and may be also hermaphrodite or with separated genders, and present white, pink or purple color, depending on each species (Joly, 1998).

Vernonia polyanthes is commonly known in Brazil as assa-peixe, chamarrita, cambaráguaçu, white-cambará and white assa-peixe, and presents some synonymies as Vernonia patens Less, Vernonanthura rigiophylla, Vernonanthura phosphoric, Eupatorium polyanthes Spreg (Lorenzi \& Matos, 2008). V. polyanthes leaves have been studied and their pharmacological properties such as antinociceptive and anti-inflammatory (Temponi et al., 2012), antihypertensive and diuretic (Silveira et al., 2003a; Silveira et al., 2003b), antiulcerogenic (Barbastefano et al., 2007), antifungal and leishmanicidal (Braga et al., 2007), mutagenic and antimycobacterial (Oliveira et al., 2007; Jorgetto et al., 2011), have been established. Fixed acids, chalcones, aurones, alkaloids, aminoacids, coumarins, steroids, quinones, triterpenes, Sesquiterpene lactones, anthraquinones, flavonoids, chlorogenic acids, saponins and tannins were detected in V. polyanthes (Souza et al., 2008; Silva et al., 2010; Temponi et al., 2012; Igual et al., 2013) and may be responsible for their activity.

In case of a plant species with high pharmaco therapeutic potential in the treatment of infectious diseases, inflammatory processes and lung diseases, the present study assumes an important role in the research for the development of new plant originated drugs, since that despite of the pharmacological activities of $V$. polyanthes leaves, flowers and roots, already verified in popular uses, there are no available studies about these flowers, mainly in relation to phytochemical, microbial and pharmacological evaluations.

Thus, the aims of this study were to evaluate the antimicrobial potential of crude fractions and extracts, obtained by maceration and infusion of flowers of $V$. polyanthes, against three bacterial strains, comparing the inhibition activity between the extracts and fractions, and perform preliminary phytochemical tests aiming to qualitatively identify possible chemical components present in the flowers.

\section{MATERIAL AND METHODS \\ Plant material}

Vernonia polyanthes flowers were sampled in morning time, in March 2013, in pastures near native forests in the city of Toledo, Paraná State,
Brazil (2445'5.95's; 5348'9.36”'W). Species identification was performed by Marizete Gonçalves da Silva from the Pontifical Catholic University of Paraná, and the voucher specimen was deposited in the Herbarium of Pontifical Catholic University of Paraná, under no. HUCP: 2326.

\section{Fractionation of crude extracts}

After drying in circulating air oven at $40^{\circ} \mathrm{C}$ for three days, $V$. polyanthes flowers were macerated and kept in a hermetically sealed container, protected from light. Then aqueous and alcoholic extracts were prepared. The aqueous extract was obtained by 12 minutes infusion in hot water in the proportion of 1:10 (plant: water), followed by filtration and lyophilization (K115-LIOTOP). The alcoholic extract was prepared through $99.95 \%$ methanol maceration in the proportion of 1:10 (plant:solvent) for seven days with daily agitation. After filtering, the macerate concentrated in a rotary evaporator (SISATAM 804).

To crude extracts $(15 \mathrm{~g})$ were added $180 \mathrm{~mL}$ water and partitioned in $180 \mathrm{~mL}$ hexane, dichloromethane and ethyl acetate. The organic solvent was evaporated in a vacuum evaporator and the aqueous fraction was lyophilized to obtain fractions of hexane, dichloromethane, ethyl acetate and water.

\section{Content of extractives of plant extracts}

All analyses were conducted at $25{ }^{\circ} \mathrm{C}$ in triplicate. The content of extractives for obtaining the residual weight after evaporation of the solvent.

\section{Preliminary phytochemical evaluation}

The preliminary phytochemical evaluation of the components of aqueous and alcoholic extracts was performed through colorimetric and precipitation tests to observe the presence of flavonoids (Shinoda's and sodium hydroxide tests), saponins (foaming index), tannins (iron salts, lead acetate, gelatin and copper acetate reactions), anthraquinones (Borntraeger's test) and alkaloids (Mayer's, Bertrand's, Dragendorff's and Bouchardat's precipitation reactions) as described by Goyal et al. (2010).

\section{Thin layer chromatography (TLC)}

Extracts were analyzed using silica-gel 60 GF254 plates (Merck®, $0.25 \mathrm{~mm}$ thick). The analyzes were conducted with specific mobile phases and developers to flavonoids, tannins and alkaloids (farmacopéia brasileira, 1977), to confirm the results observed in colorimetric tests.

Flavonoids: plates were eluted with ethyl acetate:formic acid:water (90:5:5) and exposed to ammonia gas.

Tannins: plates were eluted with ethyl

Rev. Bras. PI. Med., Campinas, v.17, n.4, supl. II, p.909-914, 2015. 
acetate:formic acid:water (90:5:5) and developed with ferric chloride $(0.1 \%)$ and potassium ferricyanide $(0.1 \%)$ reagents $(1: 1)$.

Alkaloids: mobile phase was chloroform: methanol:ammonium hydroxide (9.7:0.3:0.025). Dragendorff's reagent was used as a developer, and then was observed under UV (254 and $365 \mathrm{~nm}$ ).

\section{Microbiological assay}

For the preparation of the paper disks used in the microbiological assay, $120 \mathrm{~g}$ of each extract were weighed and ressuspended in 600 $\mu \mathrm{L}$ of their respective solvents. The disks sterilized by autoclaving (6 $\mathrm{mm}$ diameter, Laborclin ${ }^{\circledR}$, Brazil) were placed in petri dishes and impregnated with 30 and $60 \mu \mathrm{L}$ of each fraction (concentrations of 6 and $12 \mathrm{mg} /$ disk, respectively) and taken to oven for total evaporation of the solvent, at $37^{\circ} \mathrm{C}$ for 12 hours. These concentrations were selected based on results of studies using medicinal plants or tannins, flavonoids and/or alkaloids isolated (Jayasutha et al., 2011; Mohammed et al., 2013; Zhang et al., 2014).

The evaluation of antimicrobial activity was performed in duplicate for all extracts, by the paper disk agar diffusion method, following the standard rules of antimicrobial sensitivity tests by disk-diffusion by the Clinical and Laboratory Standards Institute (CLSI, 2015). For the survey of microbiological activity, strains of Escherichia coli (ATCC 25922), Staphylococcus aureus (ATCC 27853) and Pseudomonas aeruginosa (ATCC 25923) were used. The strains were obtained commercially from Newprov and Laborclin laboratories.

After the dilution of microorganisms by following the $0.5 \mathrm{McF}$ arland scale (Probac ${ }^{\oplus}$ ), with the aid of sterile swabs, bacteria were gently applied on Mueller Hinton agar dishes. In sequence, sterile disks impregnated with extracts of $V$. polyanthes, were placed over the dish containing the microorganisms, one for each concentration in each dish. As negative control, one disk containing deionized sterile water and another containing the solvent previously used to ressuspension of the extract was also placed on the dishes. For each bacterium one dish was used, and the following disks of antibiotics were applied as interpretation standards: amoxicilin (AMO), vancomycin (VAN), tetracycline (TET), ceftriaxone (CRO) and penicillin G (PEN). All dishes were incubated in an oven at $35^{\circ} \mathrm{C}$, for 18 - 24 hours. After incubation period, each dish was examined and inhibition halo diameter was measured, using digital caliper rule.

\section{RESULTS}

The preliminary phytochemical evaluation allowed observing the presence of tannins and flavonoids in the aqueous extract, and tannin, flavonoids and alkaloids in the methanolic extract (Table 1) of Vernonia polyanthes flowers.

TABLE 1. Results obtained in phytochemical identification/evaluation.

\begin{tabular}{lcc}
\hline Method & Macerated & Infusion \\
Compounds & & \\
\hline Anthraquinone & - & - \\
Saponin & - & - \\
Tannin & + & + \\
Flavonoid & + & + \\
Alkaloid & + & - \\
\hline
\end{tabular}

By analyzing the extractions by TLC it was possible to confirm the colorimetric results. Both extracts in the presence of ammonia gas, revealed yellow colored patches ( $R f$ value 0.45 for both), indicating the presence of flavonol derivatives, and in contact with ferric chloridepotassium ferricyanide reagents developed dark blue spots (Rf values 0.70 and 0.68 for macerated and infusion extracts, respectively) confirming the presence of tannins. Only the extract macerated in methanol allowed visualization of orange color spot after spraying the Dragendorff's reagent (Rf: 0.36 ). The chromatographic profile of both extracts presented very similar results, allowing to infer that water has an extractive capacity comparable to methanol, diverging, mainly, in the concentration of the extracted compounds; given by the extractive level (Table 2) and showing small variation in relation to the classes of extracted compounds. As previously observed through colorimetric tests, the only difference between the crude extracts was given to the presence of alkaloids in the methanol extracts, which was sometimes extracted in non-detectable quantities in the aqueous extract.

After the agar diffusion assay, it was possible to observe that only the ethyl acetate from both extracts presented inhibition over the microorganism Staphylococcus aureus (Table 3). The other extracts did not present alteration over the microbial growth.

\section{DISCUSSION}

In the agar disk diffusion, a comparison is performed to a reference biological pattern (positive control) and the zone of growth inhibition is measured starting from the disk circumference (Ostrosky et al., 2008). There is no consensus on the acceptable level of inhibition for natural products when compared with antibiotics standards. Some authors consider only results similar to antibiotics, while others consider with good potential even those 
Table 2. Content of extractives (\%) of extracts and fractions of $V$. polyanthes.

\begin{tabular}{lcc}
\hline Extract/Fraction & Macerated & Infused \\
\hline Crude & 12.30 & 16.66 \\
Hexane & 12.09 & 0.01 \\
Dichloromethane & 0.81 & 0.02 \\
Ethylacetate & 2.54 & 0.53 \\
Aqueous & 20.63 & 45.86 \\
\hline
\end{tabular}

with lower levels of inhibitions (Almeida et al, 2014). The microbial assay showed bacterial inhibition against Staphylococcus aureus only with using ethyl acetate fraction in both extracts (macerated and infused), in both concentrations applied. These results are in accordance with Kelmanson et al. (2000), using methanol and ethyl acetate extracts obtained from leaves, stems and roots of Vernonia colorata on the bacteria Bacillus subtilis, Escherichia coli, Klebsiella pneumoniae, Micrococus luteus, Pseudomonas aeruginosa, Staphylococcus aureus and Staphylococcus epidermidis. Akinpelu (1999) also verified antimicrobial activity of the methanol extracts obtained from Vernonia amygdalina flowers, using the agar diffusion method, which showed sensitivity over the bacteria Bacillus subtilis, Klebsiela pneumoniae, Pseudomonas aeruginosa, Proteus vulgaris, Shigella disenteriae and Staphylococcus aureus. Furthermore, it is observed that the doses used in this study are significantly lower than doses of antibiotics standards, thus, the ethyl acetate fractions of both extracts showed satisfactory antimicrobial activity, so these results can be promising.

The difference of various plant extracts in the antimicrobial activity is expected, as the activity is based not only on the different structures of microorganisms but also on their susceptibilities (Zhang et al., 2014). This inhibitory action could be attributed to the tannins and flavonoids, since these constituents are well established as antimicrobial agents (Nenaah, 2013; Aguilar-Galvez et al., 2014;
Bagla et al., 2014; Rodrigues et al., 2014; Zhang, Wang \& Xu, 2014) and, they are present in the infusion and macerated extracts.

Studies have shown that there are several types of flavonoids that present biological activity, which produce significant anti-inflammatory (Calixto, 2000) and antimicrobial action (Schlemper et al., 1998; Sartori et al., 2003). Antimicrobial activity of the flavonoids is probably related to its capacity in complexing extracellular and soluble proteins such as structures from bacterial cell walls. Lipophilic flavonoids promote the rupture of microbial membranes. This mechanism is not completely understood, due to conflicting findings: flavonoids with few hydroxyl groups in their rings are more active against microorganisms than those with more hydroxyls, which leads to the belief that the target is the microbial membrane, since is accepted that lipophilic compounds may break up this structure. On the other hand, other authors have observed the opposite effect: the higher the number of hydroxyls, higher is the activity (Chabot et al., 1992).

Tannins in general are phenolic compounds with antioxidant, astringent, antiparasitic, antiviral, and antibacterial properties (Aguilar-Galvez et al., 2014). There are several reports on the use of tannins in treating various diseases in humans, including snake bites, diarrhoea, gastric ulcers and wounds (Pereira et al., 2001; Palombo, 2006). Hydrolysable tannins and derivatives have shown bacteriostatic and bactericidal activities

TABLE 3. Mean diameter of the inhibition halos obtained by the paper disk agar diffusion method, with Staphylococcus aureus (ATCC 27853) as test microorganism, incubation time of 24 hours, temperature $35 \pm 2{ }^{\circ} \mathrm{C}$.

\begin{tabular}{lcc}
\hline Compound & Concentration $(\mathbf{m g} /$ disk $)$ & Mean inhibition halo diameter $(\mathbf{m m})$ \\
\hline EaFAE & 6 & 8.75 \\
& 12 & 9.76 \\
EaFME & 6 & 10.00 \\
& 12 & 11.00 \\
Amoxicillin & 30 & 33.0 \\
Vancomycin & 30 & 21.3 \\
Tetracycline & 30 & 28.6 \\
Ceftriaxone & 30 & 30.9 \\
Penicillin G & 30 & 37.8 \\
\hline
\end{tabular}

(EaFAE): Ethyl acetate Fraction of Aqueous Extract; (EaFME): Ethyl acetate Fraction of Methanol Extract

Rev. Bras. PI. Med., Campinas, v.17, n.4, supl. II, p.909-914, 2015. 
against Aeromonas hydrophila, Enterobacter sakazakii, Escherichia coli, Klebsiella pneumoniae, Listeria monocytogenes, Staphylococcus aureus, Salmonella Typhi and Salmonella Typhimurium (Kim et al., 2010). The antimicrobial properties of tannins could be associated with the hydrolysis of ester linkage between gallic acid, and multiple esters with D-glucose, which affects the biosynthesis steps in the syntheses of cell membrane and cell walls, causing a decrease in cell volume, by the disjunction of cell membrane from the cell wall (Cowan, 1999; Suraya \& Darah, 2002).

In the decade of 1940, when the industrialization of penicillin was started, about $90 \%$ of Staphylococcus aureus isolates were sensitive to this antibiotic. However, in the present day is observed multiple resistances of many microorganisms to various antibiotics available. Thus, government has set as one of its priority targets the development of new antimicrobial drugs using plants from Brazilian flora (Jorgetto et al. 2011).

Previous studies have already shown that methanol, ethyl acetate, chloroform and hexane extracts obtained from Vernonia toreana flowers presented antimicrobial activity against Staphylococcus aureus, Streptococcus faecalis, Bacillus subtilis, Shigella dysenteriae, Klebsiella pneumonia, Pseudomonas aeruginosa and Proteus vulgaris. Extracts from the barks showed antifungal activity against Candida albicans and Aspergillus niger while leaf extracts were inactive against isolated fungus, with the chloroform extract from both parts of the plant showingthe highest activity (Ogundare, Adetuyi \& Akinyosoye, 2006). Probably the differences are due to the use of different parts of the plant and of other species, possibly leading to the extraction of different compounds, also with antimicrobial activity.

In the present study, in the agar diffusion assay, we have observed that the fractions of ethyl acetate of both extracts presented activity against Staphylococcus aureus; and the fraction obtained from the methanol extract showed a larger inhibition halo, enabling to observe the extraction potential of the solvent employed. Differences in the activity between the extracts and fractions can be partly explained by qualitative and quantitative variations in the secondary metabolites present in the extracts and fractions.

The results obtained showed the good antimicrobial activity of the ethil acetate fractions of $V$. polyanthes, as reported by popular medicine, which has been using $V$. polyanthes for many generations. However to obtain clearer and more accurate results, studies of isolation and identification of the active compounds responsible for the activity are made necessary.

\section{REFERENCES}

AGUILAR-GALVEZ, A. et al. Potential of tara (Caesalpinia spinosa) gallotannins and hydrolysates as natural antibacterial compounds. Food Chemistry, v.156, p.301-304, 2014.

AKINPELU, D.A. Antimicrobial activity of Vernonia amigdalina leaves. Revista de Fitoterapia, v.70, p.432434, 1999.

ALMEIDA, J.R.G.S. et.al. Atividade antioxidante, citotóxica e antimicrobiana de Annona vepretorum Mart. (Annonaceae). Revista Brasileira de Fruticultura, v.36, p.258-264, 2014.

BAGLA, V.P. et al. Antimicrobial activity, toxicity and selectivity index of two bioflavonoids and a flavone isolated from Podocarpus henkelii (Podocarpaceae) leaves. BMC Complementary \& Alternative Medicine, v.14, p.383-388, 2014.

BARBASTEFANO, V. et al. Vernonia polyanthes as a new source of antiulcer drugs. Fitoterapia, v.78, p.545-551, 2007.

BRAGA, F.G. et al. Antileishmanial and antifungal activity of plants used in traditional medicine in Brazil. Journal of Ethnopharmacology, v.111, p.396-402, 2007.

CALIXTO, J.B. Efficacy, safety, quality control, marketing and regulatory guidelines for herbal medicines (phythoterapeutic agents). Brazilian Journal of Medical and Biological, v.33, p.179-189, 2000.

CHABOT, S. et al. Hyphal growth promotion in vitro of the VA mycorrhizalfungus. Gigaspora margarita Becker and Hall, by the activity of structurally specific flavonoid compounds under $\mathrm{CO}$ enriched conditions. New Phytology, v.122, p. 461-467, 1992.

CLSI - Clinical and Laboratory Standards Institute. Methods for antimicrobial dilution and disk susceptibility testing of infrequently isolated or fastidious bacteria. Approved standard M45-A2. 3 ed. Wayne, PA: Clinical and Laboratory Standards Institute, 2015. 99p.

COWAN, M.M. Plant products as antimicrobial agents. Clinical Microbiology Reviews, v.12, n.4, p.564-582, 1999.

FARMACOPÉIA BRASILEIRA. 3 ed. São Paulo: Organização Andrei, 1977. 1213p.

GOYAL, A.K. et al. Evaluation of the DPPH radical scavenging activity, total phenols and antioxidant activities in Indian wild Bambusa vulgaris "Vittata" methanolic leaf extract. Journal of Natural Pharmaceuticals, v.1, p.40-45, 2010.

IGUAL, M.O. et al. Sesquiterpene lactones, chlorogenic acids and flavonoids from leaves of Vernonia polyanthes Less (Asteraceae). Biochemical Systematics and Ecology, v.51, p.94-97, 2013.

JAYASUTHA, J. et al. Development of formulation containing extracts of Aristolochia bracteata and Cassia tora - evaluation of antimicrobial activity. International Journal of Pharmacy and Pharmaceutical Sciences. v.3, n.4, p.348-350, 2011.

JOLY, A.B. Botânica: Introdução à taxonomia Vegetal. 12 ed. São Paulo: Nacional, 1998. 808p.

JORGETTO, G.V. et al. Ensaios de atividade antimicrobiana in vitro e mutagênica in vivo com extrato de Vernonia polyanthes Less (Assa-peixe). Revista do Instituto 
Adolfo Lutz, v.70, n.1, p.53-61, 2011.

KELMANSON, J.E. et al. Zulu medicinal plants with antibacterial activity. Journal of Ethnopharmacology, v.69, p.241-246, 2000.

KIM, T.J. et al., Enhanced antioxidant capacity and antimicrobial activity of tannic acid by thermal processing. Food Chemistry, v.118, n.3, p.740-746, 2010.

LORENZI, H.; MATOS, F.J.A. Plantas medicinais no Brasil - nativas e exóticas. 2 ed. São Paulo: Instituto Plantarum, 2008. 512p.

MOHAMMED, G.T. et al. Antimicrobial efficacy of fractions from the most active ethanolic column fraction of the stem-bark of Zizyphusspina Christi (Desf). Journal of Chemical and Phamaceutical Research, v.5, n.2, p.29-35, 2013.

NENAAH, G. Antimicrobial activity of Calotropis procera Ait. (Asclepiadaceae) and isolation of four flavonoid glycosides as the active constituents. World Journal of Microbiology and Biotechnology, v.29, n.7, p.12551262, 2013.

OGUNDARE, A.O. et al. Antimicrobial activities of Vernonia tenoreana. African Journal of Biotechnology, v.5, n.18, p.1663-1668, 2006.

OLIVEIRA, D.G. et al. Antimycobacterial activity of some Brazilian indigenous medicinal drinks. Revista de Ciências Farmacêuticas Básica e Aplicada, v.28, p.165-169, 2007.

OSTROSKY, E.A. et al. Métodos para avaliação da atividade antimicrobiana e determinação da Concentração Inibitória Minima (CIM) de plantas medicinais. Revista Brasileira de Farmacognosia, v.18, n.2, p. 301-307, 2008.

PALOMBO, E.A. Phytochemicals from traditional medicinal plants used in the treatment of diarrhoea: modes of action and effects on intestinal function. Phytotherapy Research, v.20, n.9, p.717-724, 2006.

PEREIRA, L.M.S. et al. Gastric antiulcer effect of Rhizophora mangle L. Journal of Ethnopharmacology, v.77, n.1, p.1-3, 2001.

RODRIGUES, C.G. et al. Antibacterial activity of tannins fromm Psidium guineese Sw. (Myrtaceae). Journal of Medicinal Plant Research, v.8, n.35, p.1095-1100, 2014.
SARTORI, M.R.K. et al. Antifungal activity of fractrions and two pure compounds of flowers from Wedelia paludosa (Acmela brasiliensis) (Astearaceae). Pharmazie, v.58, n.8, p.567-569, 2003.

SCHLEMPER, S.R.M. et al. Atividade antibacteriana de frações semipurificadas e compostos puros de Wedelia paludosa (Compositae). Alcance, v.5, n.2, p.14-18, 1998.

SILVA, N.C.C. et al. Biological properties of medicinal plants: a review of their antimicrobial activity. The Journal of Venomous Animals of Toxins including Tropical Diseases, v.16, n.3, p-402-413, 2010.

SILVEIRA, R.R. et al. Modificações da diurese e da pressão arterial em ratos Wistar anestesiados, após administração de infuso de assa-peixe (Vernonia polyanthes Less). Revista Brasileira de Plantas Medicinais, v.2, p.31-35, 2003â.

SILVEIRA, R.R. et al. Effect of the crude extract of Vernonia polyanthes Less. on blood pressure and renal sodium excretion in unanesthetized rats. Phytomedicine, v.10, p.127-131, 2003ㅁ.

SOUZA, F.A. et al. Caracterização fitoquímica preliminar de infusões populares obtidas das partes aéreas das espécies Apium leptophylum (Pers.) F. Muell. ex Benth. (Apiaceae), Elvira biflora L. (DC.) e Vernonia polyanthes Less. (Asteraceae). Revista Brasileira de Farmácia, v.89, p.24-27, 2008.

SURAYA, S.; DARAH, I. Sem and TEM studies of the structural modifications of Candida albicans cells after treatment with extract from Cuculigo latifolia Dryand. Proceedings of The Fourth Regional IMT-GT UNINET Conference, Penang, Malaysia, p. 203-205, 2002.

TEMPONI, V.S. et al. Antinociceptive and Anti-Inflammatory Effects of Ethanol Extract from Vernonia polyanthes Less in Robents. International Journal of Molecular Sciences, v.13, n.3, p.3887-3899, 2012.

ZHANG, L.L. et al. Preparation and antimicrobial activity of tannin polymers from Platycarya strobilacea infructescence. Materials Research Innovations, v.18, p.S21046-S21049, 2014.

ZOMLEFER, W.B. Guide to flowering plant families. 1 ed. Chapel Hill: The University of North Caroline Press, 1994. 430p.

Rev. Bras. PI. Med., Campinas, v.17, n.4, supl. II, p.909-914, 2015. 